Report Title:

\title{
PHASE II CALDERON PROCESS TO PRODUCE DIRECT REDUCED IRON \\ RESEARCH AND DEVELOPMENT PROJECT
}

Report Type: QUARTERLY Reporting Period Start Date:10/01/2006 End Date: 12/31/2006

Principal Author(s): ALBERT CALDERON

Report Issue Date: $01 / 30 / 2007$

DOE Award No.: DE- FC22 -95PC92638

Submitting

Organization(s)

Name \& Address
CALDERON ENERGY COMPANY

500 Lehman Avenue

P.O. Box 126

(1)

Bowling Green, OH 43402

(3) 


\section{DISCLAIMER}

This report was prepared as an account of work sponsored by an agency of the United States Government. Neither the United States Government nor any agency thereof, nor any of their employees, makes any warranty, express or implied, or assumes any legal liability or responsibility for the accuracy, completeness, or usefulness of any information, apparatus, product, or process disclosed, or represents that its use would not infringe privately owned rights. Reference herein to any specific commercial product, process, or service by trade name, trademark, manufacturer, or otherwise does not necessarily constitute or imply its endorsement, recommendation, or favoring by the United States Government or any agency thereof. The views and opinions of authors expressed herein do not necessarily state or reflect those of the United States Government or any agency thereof. 


\section{QUARTERLY TECHNICAL PROGRESS REPORT \\ PHASE II CALDERON PROCESS TO PRODUCE DIRECT REDUCED IRON RESEARCH AND DEVELOPMENT PROJECT \\ CALDERON ENERGY COMPANY \\ COOPERATIVE AGREEMENT NO. DE-FC22-95PC92638}

Reporting Period: 10-01-06 to 12-31-06

Date of Report: 1-30-07;

Phase II Award Date: 6-23-00; Anticipated Completion Date: 12-03-07

Total Project: $\$ 14,732,316.00$ Total DOE Share This Action: $\$ 6,457,000.00$

Contracting Officer's Representative (COR): John Stipanovich;

Project Director: Albert Calderon

Assistant Project Director: Reina Calderon

\section{$\underline{\text { Abstract }}$}

This project was initially targeted to the making of coke for blast furnaces by using proprietary technology of Calderon in a phased approach, and Phase I was successfully completed. The project was then re-directed to the making of iron units. In 2000, U.S. Steel teamed up with Calderon for a joint effort to produce directly reduced iron with the potential of converting it into molten iron or steel consistent with the Roadmap recommendations of 1998 prepared by the Steel Industry in cooperation with the Department of Energy by using iron ore concentrate and coal as raw materials, both materials being appreciably lower in cost than using iron pellets, briquettes, sinter and coke. 


\section{TABLE OF CONTENTS}

Executive Summary

Experimental Work

Results and Discussion

Conclusion

References
Page 1

Page 3

Page 4

Page 6

Page 7 


\section{Executive Summary}

The commercialization path of the Calderon technology for making a feedstock for steelmaking with assistance from DOE initially focused on making coke, and work was done which proved that the Calderon technology is capable of making good coke for hard driving blast furnaces. U.S. Steel which participated in such demonstration felt that the Calderon technology would be more meaningful in lowering the costs of making steel by adapting it to the making of iron - thus obviating the need for coke.

U.S. Steel and Calderon teamed up to jointly work together to demonstrate that the Calderon technology will produce in a closed system iron units from iron concentrate (ore) and coal competitively by eliminating pelletizing, sintering, coking and blast furnace operation. If such process steps could be eliminated, a huge reduction in polluting emissions and greenhouse gases (including $\mathrm{CO}_{2}$ ) relating to steelmaking would ensue. Such reduction will restructure the steel industry away from the very energy-intensive steelmaking steps currently practiced and drastically reduce costs of making steel.

The development of a technology to lower U.S. steelmaking costs and become globally competitive is a priority of major importance. Therefore, the development work which Calderon is conducting presently under this Agreement with the U.S. Department of Energy becomes more crucial than ever.

The work performed during the 4th Quarter of 2006, which the present Progress Report covers, was advanced on four parallel paths. The first path was the changes made to equipment to capture the $\mathrm{ZnO}$ from the electric furnace dust of Iron Dynamics, and the second path was the coming into an agreement with Altos Hornos of Mexico (AHMSA) to continue with tests for the use of its Hercules ore to metallize it with coal to produce an iron/carbon product 
which is melted to produce hot metal. The third path was the installation of a breaker to eliminate or drastically reduce the "avalanches" occurring at the discharging end of the reactor. The breaker has produced positive results. The fourth path was the designing of a new charger to enable the introduction of the oxygen lance from the charging end in order to remove the heat losses incurred by the water cooling of the lance at the discharge end. An order was issued to a fabricator to construct the new charger. 


\section{Experimental Work}

During the Quarter, seven test runs were conducted that consisted of I-213 through I219 inclusive. Test Runs I-213, I-215, and I-217 through I-219 related to Iron Dynamic's electric furnace dust for the removal of $\mathrm{ZnO}$ by mixing it with ore concentrate and coal and pyrolyzing the mixture in the reactor. These five tests were of short duration. Test Runs I-214 and I-216 related to U.S. Steel's qualification criteria of attaining $80 \%$ metallization and 72 hours of continuous operation at reasonably steady state. Table 1 tabulates the dates, the length of each test, and the number of pushes per test.

\section{Table 1}

\begin{tabular}{|c|c|c|c|c|}
\hline Test Run \# & Date 2006 & Length in Hours & $\begin{array}{c}\text { No. of } \\
\text { Pushes }\end{array}$ & Company \\
\hline I-213 & $10 / 11 \& 10 / 12$ & $23 \mathrm{hrs}: 00 \mathrm{~min}$ & 242 & SDI \\
\hline I-215 & $11 / 7 \& 11 / 8$ & $37 \mathrm{hrs}: 30 \mathrm{~min}$ & 428 & SDI \\
\hline I-217 & $12 / 6 \& 12 / 7$ & $35 \mathrm{hrs}: 30 \mathrm{~min}$ & 395 & SDI \\
\hline I-218 & $12 / 19 \& 12 / 20$ & $35 \mathrm{hrs}: 45 \mathrm{~min}$ & 405 & SDI \\
\hline I-219 & $12 / 27 \& 12 / 28$ & $35 \mathrm{hrs}: 45 \mathrm{~min}$ & 398 & SDI \\
\hline I-214 & $10 / 30 \mathrm{thru} 11 / 3$ & $82 \mathrm{hrs}: 25 \mathrm{~min}$ & 939 & U.S.S. \\
\hline I-216 & $11 / 13$ thru $11 / 17$ & $82 \mathrm{hrs}: 30 \mathrm{~min}$ & 931 & U.S.S. \\
\hline
\end{tabular}




\section{$\underline{\text { Results and Discussion }}$}

The results obtained during the tests for SDI were focused on capturing the $\mathrm{ZnO}$ after pyrolysis. A cyclone was constructed upstream of the collector with little success, as a relatively small build-up of mustard-colored $\mathrm{ZnO}$ stuck to the walls of the cyclone was observed. In the collector, the $\mathrm{ZnO}$ was quite wet and mixed with carbon. Additional test work is required to be supported with funding from SDI, which has not been approved as of the date of this report. Calderon has covered all expenses up to now.

With respect to the work relating to additional tests for AHMSA, discussions proceeded along the lines mentioned in the previous report wherein ten tons of AHMSA's Hercules ore concentrate would be prepared and shipped to Calderon. The discussion was focused on a specific test plan. By the end of December 2006, there was no approval to proceed with such plan; however, an e-mail was sent by AHMSA dated 1/22/07 to the effect that AHMSA had approved the plan except for the type of coal to be used; see Attachment 1 .

With respect to the tests relating to U.S. Steel, a breaker was installed at the discharge end of the reactor during the later part of October; see Attachment 2. A first long test (I-214) lasting in excess of 82 hours was conducted with the goal to satisfy U.S. Steel's requirement. Sampling of the iron/carbon intermediate began $7 \mathrm{hrs}$ : : $45 \mathrm{~min}$. after start-up from cold. The 76 samples that were taken were subjected to sparking by means of grindability following the standard procedure previously reported of taking four samples every hour and subjecting each sample to six grinds at different locations of the sample. 


\begin{tabular}{|c|c|}
\hline $\begin{array}{c}\text { Number } \\
\text { of } \\
\text { Samples }\end{array}$ & $\begin{array}{c}\text { Grindability } \\
\text { Factor }\end{array}$ \\
\hline 31 & 24 out of 24 \\
\hline 19 & 23 out of 24 \\
\hline 11 & 22 out of 24 \\
\hline 4 & 21 out of 24 \\
\hline 2 & 20 out of 24 \\
\hline 2 & 16 out of 24 \\
\hline 1 & 19 out of 24 \\
\hline 1 & 8 out of 24 \\
\hline 3 & 18 out of 18 \\
\hline 1 & 15 out of 18 \\
\hline 1 & Unaccounted for \\
\hline
\end{tabular}

The second long test (I-216) was conducted with the same goal of satisfying U.S. Steel, and sampling began 6 hrs. : 45 min. from cold start-up. There were 76 samples taken:

\begin{tabular}{|c|c|}
\hline $\begin{array}{c}\text { Number } \\
\text { of } \\
\text { Samples }\end{array}$ & $\begin{array}{c}\text { Grindability } \\
\text { Factor }\end{array}$ \\
\hline 27 & 24 out of 24 \\
\hline 22 & 23 out of 24 \\
\hline 13 & 22 out of 24 \\
\hline 5 & 21 out of 24 \\
\hline 2 & 20 out of 24 \\
\hline 2 & 19 out of 24 \\
\hline 1 & 18 out of 24 \\
\hline 1 & 17 out of 24 \\
\hline 1 & 17 out of 18 \\
\hline 1 & 13 out of 18 \\
\hline 1 & 12 out of 12 \\
\hline
\end{tabular}

Prior to each test the aim was to run a 72-hour test at reasonably steady state and then send the iron/carbon intermediate to U.S. Steel for analysis with respect to percent metallization. At the end of each of the tests the consensus among the Calderon employees 
was not to send the material to U.S. Steel because it was felt that the material was not good enough, despite the fact that there was no stalling of the pusher and the material did show a marked improvement by making use of the breaker, as evidenced by the grinds being $88 \%$ above 20 out of 24 in Test Run I-214 and 91\% above 20 out of 24 in Test Run I-216.

For quite some time it has been surmised within the Calderon team that the loss of heat caused by the water cooling of the lance at the discharge end might be a detriment to the quality of metallization. A decision was made after Test Run I-216 that engineering should begin in the design of a new charger for the accommodation of the oxygen lance to be inserted from the charging end of the reactor, rather than from the discharging end, in order to eliminate heat loss at the discharge end. Design of the new charger was completed and fabrication proceeded.

\section{$\underline{\text { Conclusion }}$}

During the 4th Quarter of 2006, the project met the milestone of the installation of the "breaker" and proved to be advantageous in essentially eliminating the avalanches. The work for the $1^{\text {st }}$ Quarter of 2007 is to install the new charger, debug it, and continue with testing, with the goal of meeting U.S. Steel's criteria of metallizing the iron/carbon intermediate at $80 \%$ metallization for three 72-hour tests at a reasonably steady state. 


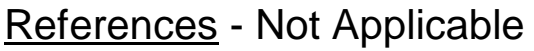

The work performed in this quarter which the report covers was original work. No reference material was relied upon for the work.

Submitted by:

Albert Calderon

Project Director 
\begin{tabular}{ll} 
From: & "Gerardo Garcia Franco" ggarciaf@gan.com.mx \\
Sent: & Mon 1/22/07 7:27 PM \\
To: & calbook@bghost.net \\
Cc: & aferriz@gan.com.mx \\
Subject: & Calderon Energy Company \\
Attachments: & \\
\hline
\end{tabular}

Hi Alberto:

First of all, happy New Year and I wish you the best for you and your family for this 2007.

Regarding Calderon Process, I want to tell you that today Mr. Ferriz had a meeting with Mr. Alonso Ancira and they talked about your proposal related with the new Test Plan.

They agree with your proposal except for the coal quality that you selected, due that is a very special coal that we believe is not available in AHMSA coal mines.

The general direction thinks that we need to advance with test but considering raw material available in AHMSA. The Idea is that you send us the characteristics of coal (including petrography) that is required for new test and we can ask to Coal Mines people about if we have available a coal with similar properties and according with that to go ahead with test.

Regards... GGF

Attachment 1 


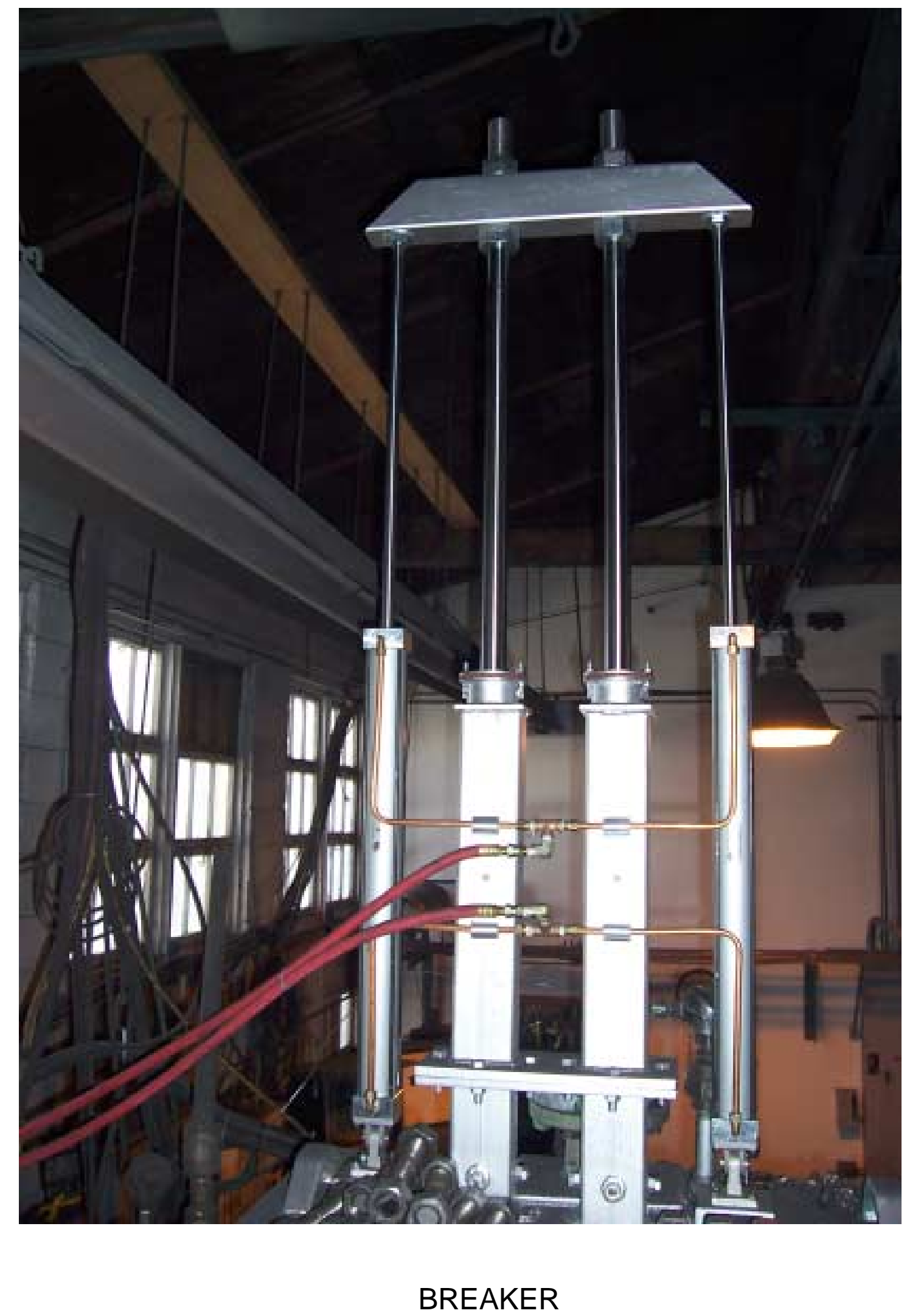

Attachment 2 